\title{
A REVIEW OF SHEAR BEHAVIOR OF CONCRETE BEAMS REINFORCED BY FRP BARS
}

\author{
*Ali AL-Sajad I. Jawad' \\ Hassan F. Hassan ${ }^{1}$ \\ Mohammed H. Kadem ${ }^{1}$ \\ 1) Civil Engineering Department, College of Engineering, Mustansiriyah University, Baghdad, Iraq
}

\begin{abstract}
Using fibre-reinforced polymer (FRP) in the concrete structures was rapidly increased throughout the past two decades. Corrosion-free properties and the high ratio of strength-to-weight of the FRP reinforcement has led to the significant increase of structures' service life. In the present work, the earlier studies that are associated with shear behaviour of the beams that have been reinforced by the FRP bars are reviewed. Many researchers have investigated shear behavior of the beams of concrete that have been reinforced by the FRP bars and determined their capacity. Some of them have per-formed experimental investigations through the testing of several beams with varying some of the parameters, whereas the others have been theoretical for estimating shear capacity of the beam. This study presents as well, a review for all of the codes and researcher equations for shear design of the beams that have been rein-forced by the FRP bars.
\end{abstract}

Keywords: Steel Fiber, Shear Strength, fiber reinforced polymer.

\section{Introduction}

The deteriorations of the concrete structures as a result of steel reinforcement corrosion resulted in the emergence of the necessity for alternative reinforcement type, like the FRP. Stirrups that are utilized for the shear reinforcement are located typically as external reinforcement based on flexural reinforcement, which is why; they have higher susceptibility to the severe environmental factors, because of minimum concrete cover that has been provided. The FRP can be defined as corrosion-free materials and were utilized lately as reinforcements for avoiding concrete structure deteriorations, which result from the steel reinforcement corrosion. Using FRP as a reinforcement for the concrete structures rapidly increased over the past decade. The reinforcement of the FRP has been made from fibers that have high-tensilestrength, like the aramid, carbon, glass, and others embedded in the polymeric matrices and produced as bars, ropes, strands, grids and tendons, in many different shapes and properties. The reinforcement of the FRP is utilized as pre-stressed, non-pre-stressed and shear reinforcement for the structures of concrete. Numerous analytical and experimental research programs were carried out for investigating flexural behavior of the concrete members reinforced and/or prestressed by the reinforcement of FRP. Using FRP as shear reinforcement for the structures of concrete was not entirely explored yet, and data that are currently available are insufficient for the formulation of rational guidelines for the design [1-7]. The reinforced and pre-stressed concrete member flexural behaviors were studied thoroughly and then rationalized to simple equations of compatibility and equilibrium in the majority of current codes. None-the-less, there has not been a clear definition of the shear mechanism and is considered to be one of the most 
complex mechanisms for rationalization to a simple mod-el. numerous models have been presented by various codes using several assumptions related to the material properties and the internal mechanism. In general, shear failure of reinforced and pre-stressed members of concrete is disastrous in nature, which is why, a considerable safety margin is normally utilized. Despite the many experimental research decades and using highly advanced analytical tools, the shear failure has not been entirely understood yet. The shear transfer in the beams of concrete is highly dependent upon compressive and tensile strength of concrete. Which is why, it is no surprise that a failure that results from the shear is brittle generally. In addition to that, in the case where the shear reinforcement has not been provided suitably for the pre-stressed or reinforced beams of concrete, shear failure will possibly occur suddenly, and with no prior distress warning. Which is why, the beams of concrete are reinforced, in general, with the shear reinforcement for ensuring that the flexural failure will take place prior to shear failure in a case of the overloading conditions for the purpose of ensuring the ductile failure. The literature about the concrete beams' shear behavior is highly extensive, due to the fact that it started from the be-ginning of the century. Which is why, it's be-yond this study's scope for encompassing all of the earlier works concerning this subject. A detailed review has been provided by ASCE-ACI Task Committee 426 (1973) [8-19].

\section{Provisions of the Shear Design for the FRP-RC Member}

\subsection{ACI 440.1R-15 Design Guidelines}

Shear capacity $V_{c f}$ of the concrete of the flexural members utilizing FRP as basic reinforcement may be specified as [20]:

$V_{c f}=\frac{2}{5} \sqrt{f c^{\prime}} b_{w} c$
Where $f_{c}$ 'represents the compressive strength of the concrete; c represents depth of cracked transformed section neutral axis; and $b_{w}$ represents the width of the web;. For the single reinforced rectangular cross sections, $\mathrm{c}=\mathrm{kd}$ and $\mathrm{k}$ can be computed from the following equation:

$k=\sqrt{2 \rho_{f} n_{f}+\left(\rho_{f} n_{f}\right)^{2}}-\rho_{f} n_{f}$

$\rho_{f}=$ FRP ratio of reinforcement and $n_{f}=E_{f} /$ $E_{\mathrm{c}}, E_{c}$ and $E_{f}$ represent elasticity moduli of concrete and longitudinal FRP bars, respectively).

Shear resistance that has been provided by the stirrups of the FRP, which are perpendicular to the member $V_{s f}$ axis may be calculated from the equation:

$$
V_{s f}=\frac{A_{f v} f_{f v} d}{S}
$$

$\mathrm{d}$ represents the effective depth; $A_{f v}$ represents the total cross-section region of the shear reinforcement in distance $s$; $s$ represents the spacing of the shear reinforcement; $f_{f v}$ represents the stress level of design in shear reinforcements of the FRP at ultimate and may be computed as:

$f_{f v}=0.004 E_{v} \leq f_{\text {fubent }}$

Bend capacity $f_{f b}$ may be specified based on the equation:

$f_{\text {fu bent }}=\left(0.05 \frac{r_{b}}{d_{b}}+0.3\right) f_{f u} \leq f_{f u}$

In the case of using the continuous FRP rectangular spirals as shear reinforcement (then, s represents pitch and $\alpha$ represents the spirals' inclination angle), Eq. (2-6) gives a contribution of FRP spirals:

$V_{s f}=\frac{A_{f v} f_{f v} d}{S} \sin \alpha$ 


\subsection{The Canadian Standard Code CAN/CSA-S 6-14}

CAN/CSA-S 6-14, 2014 utilizes identical basic formulas to the CSA A 23.3-4 (2004) for the steel-RC shear designs, however, it has been modified for the FRP through the introduction of a factor for accounting for lower FRP vs. steel elastic modulus in the case where longitudinal strain at member midheight has been calculated. The updated CSA S6-14 equation version that has been suggested in 2008 by Benmokrane and ElSayed has been given in Eq. (4-7) [21]

$V_{c f}=2.5\left(\frac{0.4}{1+1500 \varepsilon_{x}} \cdot \frac{1300}{1000+s_{z e}}\right) \phi_{c} f_{c r} b_{w} d_{v}$

Where

$\varepsilon_{x}=\frac{V_{f}\left(\frac{a}{d}+1\right)}{2\left(E_{f} A_{f}\right)}$

$A_{v, \min }=\frac{0.3 \sqrt{f^{\prime}}{ }_{c} b s}{f_{f v}}$

If $A_{v}>A_{v, \min }, S_{z e}=300 \mathrm{~mm}$

If $A_{v}<A_{v, \min ,} s_{z e}=35 s_{z} /\left(15+a_{g}\right)>0.85 s_{z}$,

Where $s_{\mathrm{z}}$ represents the parameter of the crack spacing and will be considered as $\mathrm{dv}$ or as distance between distributed longitudinal layers of the reinforcements, where every one of the intermediate layers of this reinforcement has an area that is at least of $0.003 \mathrm{~b} s_{\mathrm{z}}$.

For the members with the transverse reinforcement of the FRP, which is perpendicular to member axis $V_{s f}$ has been estimated with the use of:

$V_{s f}=\frac{A_{f v} f_{f v} d_{v}(\cot \theta+\cot \alpha) \sin \alpha}{s}$

$d_{v}=$ Greater value of $0.75 \mathrm{D}$ or $0.9 \mathrm{~d}$

Here, d represents effective depth; $A_{f v}$ represents the total cross-section region of the shear reinforcement in the distance $\mathrm{s} ; \mathrm{s}$ represents the shear reinforcement's spacing; $f_{f v}$ represents the stress level of the design in FRP shear reinforcement at ultimate and may be computed with the use of the following equation:

$f_{f v}=0.004 E_{v}, \leq f_{\text {fubent }}$

The $f_{f b}$ bend capacity may be found based on the equation below:

$f_{\text {fubent }}=\left(0.05 \frac{r_{b}}{d_{b}}+0.3\right) \frac{f_{f u}}{1.5}$

The maximal $f_{f v}$ stress has been taken as lower than $0.005 E_{v}, 0.4 f_{f u}$, or $1200 \mathrm{MPa}$, and a $\theta$ represents the diagonal compressive stress angle, which can be estimated based on:

$$
\theta=(30+7000)\left(0.888+\frac{s_{z e}}{2500}\right)
$$

\subsection{JSCE Shear Design Approach}

The shear capacity of the design that has been provided with the concrete $V_{c f}$ may be specified based on the equation below [22]:

$$
V_{c f}=\frac{\beta_{d} \beta_{p} \beta_{n} f_{v c d} b_{w} d}{\gamma_{b}}
$$

The $\gamma_{b}$ value represents the factor of strength reduction; $\beta_{d}, \beta_{p}$, and $\beta_{n}$ represent the factor of the size effect, factor that considers tensile reinforcement stiffness, and aspect that considers axial force on cross section,

Where

$$
\begin{aligned}
& f_{V c d}=0.2\left(f^{\prime}\right)^{1 / 3} \leq 0.72 \frac{\mathrm{N}}{\mathrm{mm}^{2}} \\
& \beta_{d}=\left(\frac{1000}{d}\right)^{\frac{1}{4}} \leq 1.5 \\
& \beta_{p}=\left(100 \rho_{f} E_{f} / E_{s}{ }^{1 / 3} \leq 1.5\right. \\
& \beta_{n}=1+\frac{M_{o}}{M_{d}} \quad \leq 2 \text { for } N^{\prime}{ }_{d} \geq 0 \\
& \beta_{n}=1+\frac{2 M_{o}}{M_{d}} \quad \leq 0 \text { for } N^{\prime}{ }_{d} \geq 0
\end{aligned}
$$


Where $M_{o}$ represents the decompression moment; $N^{\prime}{ }_{d}$ represents the design axial compressive force and $M_{d}$ represents the design bending moment. The shear contribution of thedesign $V_{s f}$ by vertical stirrups of the FRP is represented as:

$V_{s f}=\left[A_{f v} E_{v} \varepsilon_{f v} / s\right] \frac{z}{\gamma_{b}}$

In the case where the rectangular stirrups of the FRP have been inclined with the angle $\alpha$ that has been formed by the member axis and shear reinforcement, shear contribution $V_{s f}$ can be represented as:

$V_{s f}=\left[A_{f v} E_{v} \varepsilon_{f v}(\sin \alpha+\cos \alpha) / s\right] \frac{z}{\gamma_{b}}$

$\varepsilon_{f v}=0.0001 \sqrt{\left(\frac{h}{300}\right)^{-1 / 10} \cdot f^{\prime}{ }_{c d} \frac{\rho_{f} E_{f}}{\rho_{f v} E_{V}}} \leq \frac{f_{f u b e n t}}{E_{V}}$

$f_{\text {fu bent }}=\frac{\left(0.05 \frac{r_{b}}{d_{b}}+0.3\right) f_{f u v}}{1.3}$

Where $A_{f v}$ represents shear reinforcement's total cross-sectional area, $E_{v}$ represents Young modulus of the shear reinforcement, $\rho_{f v}$ represents shear reinforcement ratio, $\varepsilon_{f v}$ represents design value of the strain of the shear reinforcements at the ultimate limit state, $Z$ represents distance between action points of compressive and tensile resultant forces and it equals $d / 1.15, f_{\text {fu bent }}$ represents design strength of FRP stirrup bent portion, $f_{f u}$ represents the straight portion's shear reinforcement tensile strength, and $\mathrm{h}$ represents the member's total depth.

\subsection{Equation of shear design}

The shear design for the longitudinally and transversally reinforced beams by FRP bars are listed in Table1.

Table 1. Shear design formulas

Prediction $\quad$ Shear Strength Equations methods

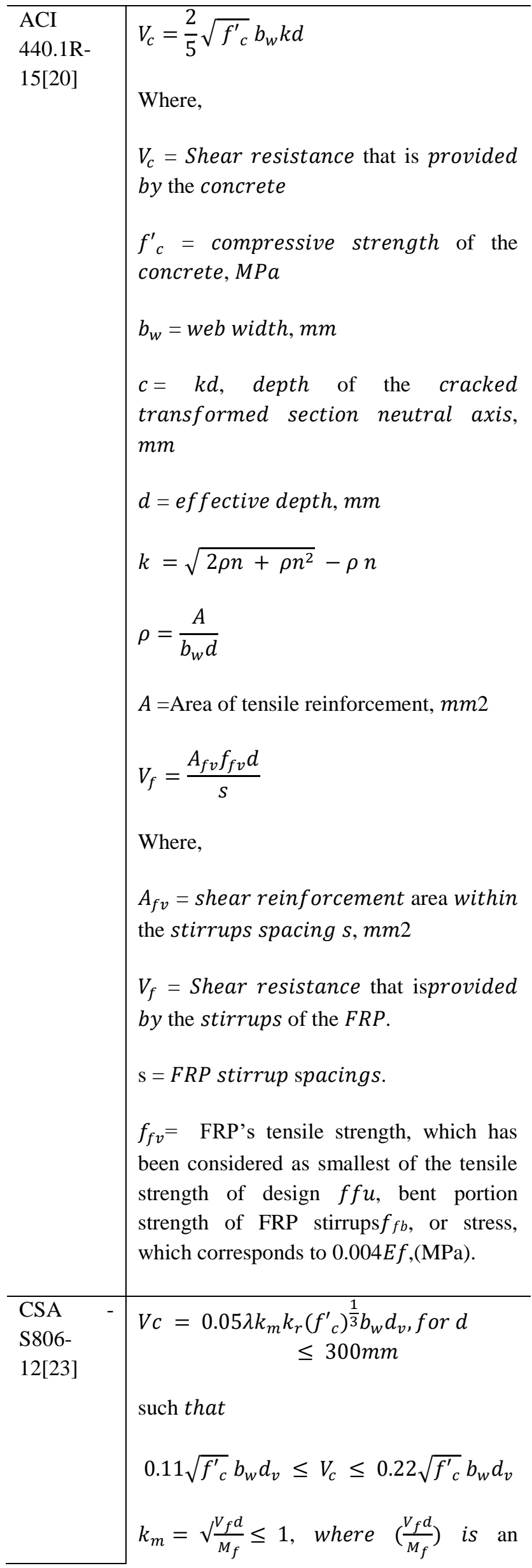




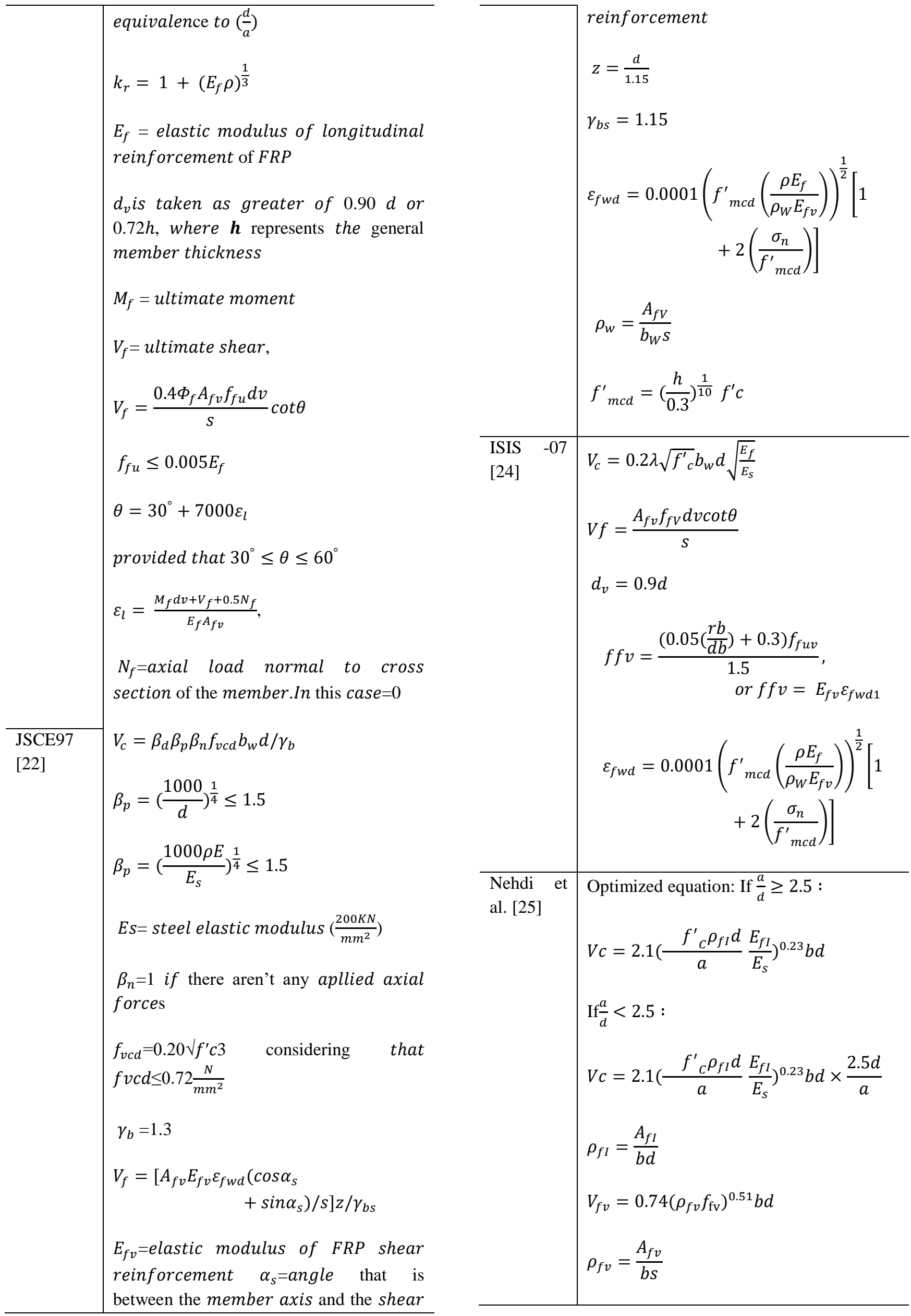




\begin{tabular}{|c|c|}
\hline $\begin{array}{l}\text { Nehdi et } \\
\text { al. [25] }\end{array}$ & $\begin{array}{l}\text { Optimized equation: If } \frac{a}{d} \geq 2.5: \\
V c=2.1\left(\frac{f^{\prime}{ }_{C} \rho_{f I} d}{a} \frac{E_{f I}}{E_{s}}\right)^{0.3} b d \\
\text { If } \frac{a}{d}<2.5: V c= \\
2.1\left(\frac{f^{\prime}{ }_{C} \rho_{f I} d}{a} \frac{E_{f I}}{E_{S}}\right)^{0.3} b d \times \frac{2.5 d}{a} \\
\rho_{f I}=\frac{A_{f I}}{b d} \\
V_{f v}=0.5\left(\rho_{f v} f_{\mathrm{fv}}\right)^{0.5} b d \\
\rho_{f v}=\frac{A_{f v}}{b s}\end{array}$ \\
\hline $\begin{array}{l}\text { Hoult et } \\
\text { al. [26] }\end{array}$ & 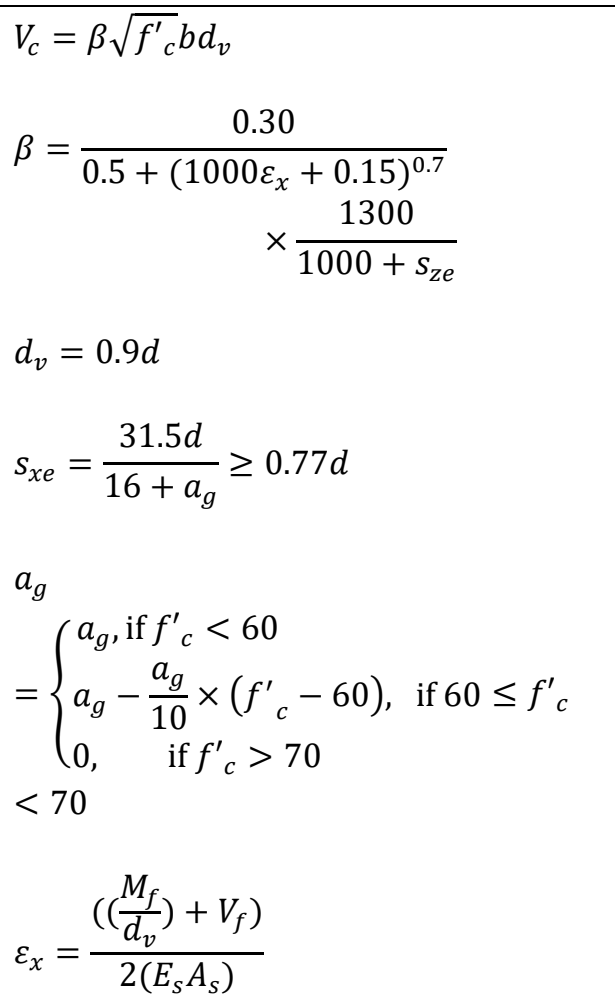 \\
\hline $\begin{array}{l}\text { Tureyen } \\
\text { and } \\
\text { Frosch } \\
{[27]}\end{array}$ & $\begin{array}{l}\text { Calculations have been performed in the } \\
\text { English units. } \\
V_{C}=\left(\sqrt{16+\frac{4 \sigma_{m}}{3 \sqrt{f^{\prime} c}}}\right) \sqrt{f^{\prime}{ }_{c}} \mathrm{bc} \\
c=k d \\
\sigma_{m}=\frac{f_{c r} I k d}{I_{c r}\left(\frac{h}{2}\right)} \\
I_{c r}=b\left(\frac{k d}{3}\right)^{3}+n_{f} A_{f}(d-k d)^{2}\end{array}$ \\
\hline
\end{tabular}

\section{Previous Work}

\subsection{Shear Behavior with FRP Stirrups}

Li, et. al. (2020) [28] the shear behavior of the 15 concrete beams that have been reinforced in the shear by the CFRP-MF (mesh fabric) configuration or with/with no steel stirrups (as the control samples) has been studied in that paper. Section dimensions of samples have been 300mm (high) x 150mm (wide). Concrete beam lengths ranged as per shear span-to-effective depth ratio. There have been 3 different ratios of shear span-depth $(\mathrm{a} / \mathrm{d}$ ratio) submitted for dividing samples to 3 groups (i.e. A, B and C) Table (2). Shear spandepth ratio values have been $1.00,2.50$, and 3.50 and beam lengths have been $1,800 \mathrm{~mm}$, $1,800 \mathrm{~mm}$ and $2,200 \mathrm{~mm}$, respectively. CFRPMF reinforced concrete beam's failure mode remained dependent upon shear span/depth ratio of the beams of concrete. The CFRP-MF has been ruptured either near flexural reinforcements or crossing through the dominating diagonal crack. Stirrups of the CFRP-MF have been found to have higher effectiveness at the confining of the core concrete compared to the steel stirrups, as a result, obtaining a larger factor of efficiency in the deep beams. 
Table 2. Summary of the parameters of specimen [28]

\begin{tabular}{|c|c|c|c|c|c|c|}
\hline $\begin{array}{l}\text { Group } \\
\text { Name }\end{array}$ & $\begin{array}{l}\text { Specimen } \\
\text { ID }\end{array}$ & $\begin{array}{l}\text { Shear } \\
\text { span-to- } \\
\text { depth } \\
\text { ratio }\end{array}$ & $\begin{array}{l}\text { Nominal area of } \\
\text { the transversal } \\
\text { shearreinforcem } \\
\text { ent }\left(\mathrm{mm}^{2}\right)\end{array}$ & $\begin{array}{c}\text { Center-to-center spacing of the } \\
\text { stirrups }(\mathrm{mm})\end{array}$ & $\begin{array}{l}\text { Nominal shear } \\
\text { reststance of } \\
\text { shear } \\
\text { reinforcements }\end{array}$ & $\begin{array}{c}\text { shear } \\
\text { reinforcement } \\
\text { ratio } \\
(\%)\end{array}$ \\
\hline \multirow[t]{5}{*}{ A } & $\mathrm{AC}$ & 1.0 & - & - & - & 0 \\
\hline & AS & & 66.4 & 150 & 31 & 0.293 \\
\hline & A150 & & 8.0 & 150 & 31 & 0.036 \\
\hline & A80 & & 8.0 & 80 & 58 & 0.067 \\
\hline & A55 & & 8.0 & 55 & 84 & 0.097 \\
\hline \multirow[t]{5}{*}{ B } & $\mathrm{BC}$ & 2.5 & - & - & - & 0 \\
\hline & BS & & 66.4 & 150 & 31 & 0.293 \\
\hline & B150 & & 8.0 & 150 & 31 & 0.036 \\
\hline & B80 & & 8.0 & 80 & 58 & 0.067 \\
\hline & B55 & & 8.0 & 55 & 84 & 0.097 \\
\hline \multirow[t]{5}{*}{$\mathrm{C}$} & $\mathrm{CC}$ & 3.5 & - & - & - & 0 \\
\hline & $\mathrm{CS}$ & & 66.4 & 150 & 31 & 0.293 \\
\hline & C150 & & 8.0 & 150 & 31 & 0.036 \\
\hline & C80 & & 8.0 & 80 & 58 & 0.067 \\
\hline & C55 & & 8.0 & 55 & 84 & 0.097 \\
\hline
\end{tabular}

Jumaa, et. al. (2019) [29] 6 high-strength large-scale beams of concrete that have been reinforced by the bars of the basalt FRP (BFRP) and stirrups and 3 equivalent beams with no stirrup have been made and tested for the shear failure under a 4-point bending. Basic parameters that have been taken under consideration were beam effective depth (300mm, 500mm, and $700 \mathrm{~mm})$ and stirrup spacing Table (3).

Table 3. Details of beam specimens [29]

\begin{tabular}{|c|c|c|c|c|c|c|c|c|c|c|c|}
\hline NO & $\begin{array}{c}\text { Specimen } \\
\#\end{array}$ & $\begin{array}{c}\text { Height; } \\
\text { h, } \\
\text { mm }\end{array}$ & $\begin{array}{l}\text { Width; } \\
\text { b, } \\
\text { mm }\end{array}$ & $\begin{array}{l}\text { Depth; } \\
\text { d, } \\
\text { mm }\end{array}$ & $\begin{array}{l}\text { Length; } \\
\text { L, } \\
\text { mm }\end{array}$ & $\begin{array}{c}\text { Shear } \\
\text { span; } \\
\text { a, } \\
\text { mm }\end{array}$ & $a / d$ & $\begin{array}{l}\text { Concrete } \\
\text { Comp. } \\
\text { Strength; } \\
\mathrm{f}_{\mathrm{c}}{ }^{\prime}, \mathrm{MPa}\end{array}$ & $\begin{array}{c}\text { Reinf. } \\
\text { Ratio; } \\
\rho_{\mathrm{f}} \%\end{array}$ & $\begin{array}{l}\text { Stirrup } \\
\text { Spacing } \\
\varnothing 8 \mathrm{~mm}\end{array}$ & $\begin{array}{c}\rho_{\mathrm{fv}} \% \\
= \\
\mathrm{A}_{\mathrm{fv}} \\
/ \mathrm{bs}\end{array}$ \\
\hline 1 & SHR3 & 300 & 200 & 234 & 2550 & 610 & 2.61 & 73.4 & 2.97 & - & - \\
\hline 2 & MHR3 & 500 & 200 & 408 & 3050 & 1070 & 2.62 & 73.4 & 2.93 & - & - \\
\hline 3 & LHR3 & 700 & 200 & 602 & 3850 & 1570 & 2.61 & 73.4 & 2.7 & - & - \\
\hline 4 & SHR3S1 & 300 & 200 & 234 & 2550 & 610 & 2.61 & 73.4 & 2.97 & 120 & 0.42 \\
\hline 5 & MHR3S1 & 500 & 200 & 408 & 3050 & 1070 & 2.62 & 73.4 & 2.93 & 200 & 0.25 \\
\hline 6 & LHR3S1 & 700 & 200 & 602 & 3850 & 1570 & 2.61 & 73.4 & 2.7 & 300 & 0.17 \\
\hline 7 & SHR3S2 & 300 & 200 & 234 & 2550 & 610 & 2.61 & 73.4 & 2.97 & 80 & 0.63 \\
\hline 8 & MHR3S2 & 500 & 200 & 408 & 3050 & 1070 & 2.62 & 73.4 & 2.93 & 135 & 0.37 \\
\hline 9 & LHR3S2 & 700 & 200 & 602 & 3850 & 1570 & 2.61 & 73.4 & 2.7 & 200 & 0.25 \\
\hline
\end{tabular}


Result showed that shear and flexural crack spacing at the mid-height of the beams with and with no stirrup have been proportionate to effective depth of a beam, $d$. The existence of the BFRP stirrups resulted in reduction of crack spacing to $0.36 \mathrm{~d}$, in comparison with $0.52 \mathrm{~d}$ in the beams with no stirrups. Which is why, crack spacing remains associated with depth of the beam, confirming the fact that the beam depth impact on the crack spacing isn't entirely eliminated, even though it has been considerably enhanced. The reduction of stirrup spacing from $d / 2$ to $d / 3$ has led to decreasing shear crack width, in particular, in the medium and small beams. The average reductions in the width of the shear crack for the large, medium, and small beams have been $4 \%, 24.50 \%$, and $37 \%$, respectively.

Osman, et al. (2018) [30] have tested 7 RC beams under 4 points loading with a variety of the shear span-to-depth ratio (a/d), vertical and longitudinal ratios of reinforcements. Each one of the RC beams has been constructed by a rectangular cross section of $100 \mathrm{~mm}$ in width, $300 \mathrm{~mm}$ in height, and a total length of a $1500 \mathrm{~mm}$. One of those beams has been taken under consideration as control beam, whereas the (RC1-RC6) beams have been reinforced by a variety of the reinforcement ratios. (RC0 \& RC1) beams have been reinforced by $2 \emptyset 12 \mathrm{~mm}, \mathrm{RC} 2$ Beam has been reinforced by $4 \varnothing 12 \mathrm{~mm}$, and (RC3-RC6) Beams have been reinforced by $6 \varnothing 12 \mathrm{~mm}$ deformed bars at tension face, whereas all beams have been reinforced by $2 \varnothing 10 \mathrm{~mm}$ distorted bars at compression face Table 4. Vertical and longitudinal reinforcement ratios have been studied experimentally, reinforcement ratio of the stirrups has a massive impact on crack depth and shear strength compared to the other factors. Primary shear crack inclination influences contribution of the shear reinforcement's shear strength. Results that have been obtained with the use of the ANSYS finite element has been rather similar to experimental ones, with a maximal variation of $5 \%$ in each one of the samples. A comparison between results of $\mathrm{FE}$ and $\mathrm{ACI}$ standard code has shown computational models' validity in the capture of structural responses of the contribution of the FRP with a variation that ranged at $(12-20) \%,(10-16)$ $\%$, and (13-19)\% respectively for the Ujacketing, full wrapping, and side bonding.

Table 4. Specimen details [30]

\begin{tabular}{cccccc}
\hline N0 & Specimen & $\boldsymbol{a} / \boldsymbol{d}$ & $\begin{array}{c}\text { Bott. } \\
\text { steel }\end{array}$ & $\begin{array}{c}\text { Top } \\
\text { steel }\end{array}$ & stirrup \\
\hline 1 & $\mathrm{RC} 0$ & 1.5 & $2 \emptyset 10$ & $2 \emptyset 10$ & - \\
2 & $\mathrm{RC} 1$ & 1.5 & $2 \emptyset 10$ & $2 \emptyset 10$ & $\emptyset 6 @ 150$ \\
3 & $\mathrm{RC} 2$ & 1.5 & $4 \emptyset 10$ & $2 \emptyset 10$ & $\emptyset 6 @ 150$ \\
4 & $\mathrm{RC} 3$ & 1.5 & $6 \emptyset 10$ & $2 \emptyset 10$ & $\emptyset 6 @ 150$ \\
5 & $\mathrm{RC} 4$ & 2.0 & $6 \emptyset 10$ & $2 \emptyset 10$ & $\emptyset 6 @ 150$ \\
6 & $\mathrm{RC5}$ & 2.0 & $6 \emptyset 10$ & $2 \emptyset 10$ & $\emptyset 6 @ 100$ \\
7 & $\mathrm{RC6}$ & 1.5 & $6 \emptyset 10$ & $2 \emptyset 10$ & $\emptyset 6 @ 100$ \\
\hline
\end{tabular}

Kim,et al.(2015) [31] studied the shear capacity of the concrete beams that have been reinforced by plates of GFRP as the shear reinforcement. For the purpose of examining shear performance, they have produced and tested totally 8 samples. The test variables included GFRP strip-width-to-spacing ratio and opening array type. A specimen with the GFRP plate with $3 \times 2$ opening array has shown the maximum value of the shear strength, the test included 6 type A, 1 type B, and 1 type C (Figure1).They found that the height and width of an opening have to be larger than 100 $\mathrm{mm}$, and the openings' area ratio has to be higher than $50 \%$ for the purpose of obtaining an effective shear performance, 3 different results from 3 different reinforcing plate shapes have shown that the increase of bonded area between concrete and GFRP plate results in increasing shear reinforcement efficiency. 


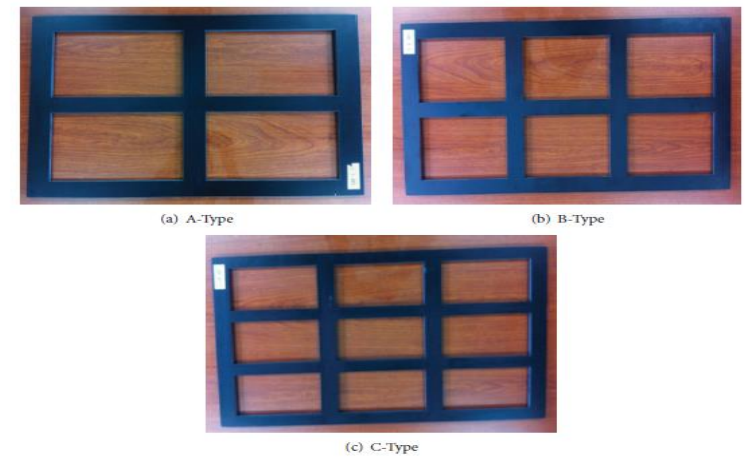

Figure 1. Designs of the 2 experimental plates of the GFRP [31]

Abdul Hamid et. al. (2013) [32] this research presented the test results of the simply supported beams of concrete, which have been reinforced longitudinally either through the steel or the GFRP. There have been totally 16 large-scale beams of concrete with steel stirrups that have been constructed and tested under 4-point monotonic load until the point of the failure.
Half of the beams have been reinforced longitudinally by the GFRP bars, whereas the rest of them have been reinforced by the conventional bars of steel as control samples, the beams have been cast on same day from same ready-mix batch of concrete with a $24 \mathrm{MPa}$ compressive strength on a 28 day period, with maximal $20 \mathrm{~mm}$ aggregate size. The conventional steel reinforcing bars and sand-coated V-Rods of the GFRP have been utilized as longitudinal reinforcements in the concrete beams. There have been 2 beam types constructed and tested, which are: GFRP RC beams (BGM) and steel RC beams (BSM).

Table 5. Details of test beams and variables [32]

\begin{tabular}{|c|c|c|c|c|c|c|c|c|c|c|c|}
\hline \multirow[t]{2}{*}{ Specimens } & \multirow[t]{2}{*}{$\begin{array}{c}\mathbf{a} \\
(\mathbf{m m})\end{array}$} & \multirow[t]{2}{*}{ a/d } & \multirow[t]{2}{*}{$\begin{array}{c}\mathbf{L} \\
(\mathbf{m m})\end{array}$} & \multirow[t]{2}{*}{$\begin{array}{c}\text { La } \\
(\mathbf{m m})\end{array}$} & \multirow[t]{2}{*}{$\begin{array}{c}\text { Ltotal } \\
(\mathbf{m m})\end{array}$} & \multicolumn{2}{|c|}{$\begin{array}{l}\text { Shear Reinforcement } \\
\text { (mild steel } 8 \mathrm{~mm} \text { dia.) }\end{array}$} & \multicolumn{4}{|c|}{ Longitudinal Reinforcement Bars } \\
\hline & & & & & & $\mathbf{s}(\mathbf{m m})$ & $\rho_{s}(\%)$ & Type & $\mathbf{N}$ & $A_{s} \& A_{s}{ }^{\prime}$ & $\begin{array}{c}\boldsymbol{\rho}_{s} \& \boldsymbol{\rho}_{\boldsymbol{s}} \\
(\%)\end{array}$ \\
\hline BSM-01 & 550 & 1.5 & 1500 & 250 & 2000 & 50 & 1.01 & Steel & 2 & 402.1 & 0.6 \\
\hline BSM-02 & 550 & 1.5 & 1500 & 250 & 2000 & 50 & 1.01 & Steel & 3 & 603.2 & 0.8 \\
\hline BSM-03 & 550 & 1.5 & 1500 & 250 & 2000 & 150 & 0.34 & Steel & 2 & 402.1 & 0.6 \\
\hline BSM-04 & 550 & 1.5 & 1500 & 250 & 2000 & 150 & 0.34 & Steel & 3 & 603.2 & 0.8 \\
\hline BSM-05 & 1100 & 3.0 & 2600 & 200 & 3000 & 50 & 1.01 & Steel & 2 & 402.1 & 0.6 \\
\hline BSM-06 & 1100 & 3.0 & 2600 & 200 & 3000 & 50 & 1.01 & Steel & 3 & 603.2 & 0.8 \\
\hline BSM-07 & 1100 & 3.0 & 2600 & 200 & 3000 & 150 & 0.34 & Steel & 2 & 402.1 & 0.6 \\
\hline BSM-08 & 1100 & 3.0 & 2600 & 200 & 3000 & 150 & 0.34 & Steel & 3 & 603.2 & 0.8 \\
\hline BGM-01 & 550 & 1.5 & 1500 & 250 & 2000 & 50 & 1.01 & GFRP & 2 & 402.1 & 0.6 \\
\hline BGM-02 & 550 & 1.5 & 1500 & 250 & 2000 & 50 & 1.01 & GFRP & 3 & 603.2 & 0.8 \\
\hline BGM-03 & 550 & 1.5 & 1500 & 250 & 2000 & 150 & 0.34 & GFRP & 2 & 402.1 & 0.6 \\
\hline BGM-04 & 550 & 1.5 & 1500 & 250 & 2000 & 150 & 0.34 & GFRP & 3 & 603.2 & 0.8 \\
\hline
\end{tabular}




\subsection{Shear Behavior without FRP Stirrups}

Kotynia et. al. (2018) [33] have performed experimental tests on $12 \mathrm{~T}$-shaped beams of concrete that have been reinforced by the GFRP or the steel bars with no stirrups. The objective of this study has been analyzing the impact of a longitudinal reinforcement type (steel or GFRP) on the deformability and the shear capacity of the concrete beams with no stirrups and for investigating a dowel impact of reinforcement on shear strengths. Beams have mostly varied according to the flexural reinforcement type, its ratio of reinforcement ( $1.40 \%$ and $1.8 \%$, the diameter of the bars, number of bars, and the number of layers of reinforcement (1 or 2), The test program comprised 12 T-section single span, simply supported beams of concrete with an $1800 \mathrm{~mm}$ clear span, which have been tested in 3-point monotonic load. The shear span to depth ratio, (a/deq) has been nearly three in all of the beams, 2 main beam series have been reinforced by the longitudinal steel bars ( 5 beams) and GFRP bars (7 beams) of diameter: $12 \mathrm{~mm}, 16 \mathrm{~mm}$ and $18 \mathrm{~mm}$. All of the straight steel bottom bars have been welded on vertical plate of steel, whereas the bars of GFRP have been anchored in steel box that has been filled by epoxy resins. Top longitudinal reinforcement included 2 straight bars of a diameter of $10 \mathrm{~mm}$ (steel or GFRP, respectively to the series). There have not been any stirrups along the shear span that has been tested, whereas opposite nontested shear span has been reinforced by the steel stirrup that have a diameter of $8 \mathrm{~mm}$ at $130 \mathrm{~mm}$ or $150 \mathrm{~mm}$ spacing and $14 \mathrm{~mm}$ diameter steel bent bars for the prevention of shear failure in that support, all of the beams have failed as a result of shear. Diagonal cracks have been formed in shear span that has been developed along longitudinal tensile reinforcements. The 1st flexural crack had happened in the mid-span of a beam. Throughout the increase in the load, the flexural cracks have developed and diagonal crack emerged in shear area. After that, with the development of the shear crack its width has been increased to the shear failure point. Test results have been listed in Table6, steel reinforced beams have reached a considerably greater ultimate shear strength compared to beams that have been reinforced by the GFRP, the shear crack stress has been influenced mostly by reinforcement type and strength of the concrete.

Issa ,et. at. (2016)[34] have researched shear strength and behaviors of concrete beams that have been reinforced by the basalt FRP bars with and with no shear reinforcement. A total of 6 of $200 \mathrm{~mm} \times 300 \mathrm{~mm}(8 \times 12$ in) and 6 of $300 \mathrm{~mm} \times 200 \mathrm{~mm}(12 \times 8$ in) the concrete beams have been made respectively with and with no shear reinforcements of the basalt FRP table (6). This work has included 12 of the BFRP RC-beams of which six 300m x 200mm (12x8 in) beams have been non shear reinforced (NSR) and six $200 \mathrm{~mm} \times 300 \mathrm{~mm}$ $(8 \times 12$ in) the beams have been shear reinforced (SR) by $10 \mathrm{~mm}$ of the stirrups of BFRP and No3 of the steel stirrups. The maximal length of the span for beams has been determined from Table (7) of ACI440.1 R (ACI 2006). Even though a/d ratios (7 \&5.65) has been high in the NSR-beams, they have not succeeded in the shear-tension mode. Failure has been noticed to be more brittle for the NSR-beams with greater ratio values of $\rho f=\rho f b$. All shear reinforced beams with $a=d$ ratio of $\leq 2.50$ have failed in the failure mode of shear-compression except for 3-13-SB1 beam, whereas 3-16B-3 beam had experienced a diagonal tension failure. The area of the damage has been increased with the increase in $\rho f=\rho f b$ ratio with a more noticeable BFRP stirrup failure at higher $\rho \mathrm{f}=\rho \mathrm{fb}$ ratios and/or higher $\mathrm{a}=\mathrm{d}$ ratio. 


\section{Conclusions}

1. The present work has shown that the predictions of shear strength of the FRP reinforced beams with and with no stirrups of the FRP have been in agreement with the shear properties of the reinforced concrete beams with other bars of FRP (CFRP, AFRP and GFRP). For the future works, more investigations are suggested in SR FRP beams of reinforced concrete in the case of the use of the FRP stirrups; in addition to that, a larger number of the parameters must be included like the beam dimension and the concrete strength.

2. FRP applications of the longitudinal tensile reinforcement in 2 layers have resulted in delaying shear failure and increasing shear strength by approximately $28 \%$.

3. The beams that have been reinforced by the reinforcement of the GFRP has shown higher ductility compared to beams that have been steel reinforced.

4. Shear stirrups considerably enhanced the shear strength in beams, increasing the shear resistance in FRP stirrups has been less noticeable when $\rho f=\rho f b$ ratio.

5. The models of the finite element have been capable of the accurate prediction of load capacity values for simulated reinforced concrete beams in shear with the composites of FRP. Which confirms the developed FE model validity and FE simulation reliability.

6. There has been an increase in shear capacity with an increase of $\rho \mathrm{f}=\rho \mathrm{fb}$ under an identical ratio of the span to depth $(a=d)$, whereas there has been a decrease in the shear capacity with increasing span to depth ratio $(\mathrm{a}=\mathrm{d})$.

7. The existence of the FRP stirrups doesn't entirely suppress size effects, as initial shear crack, shear resistant components analysis, shear crack width, normalized shear strength and strain in BFRP stirrups are still impacted by depth of the beam.

8. CSA S6-14 included a higher degree of the scatter.

9. ISIS-M03 has given unreliable results in calculation of concrete shear strength.

10. The equation that was designed by Nehdi et al. has been more superior in comparison with other design processes.

11. JSCE and ACI 440.1R-15 have resulted in the production of more conservative results in the calculation of transverse shear strength.

\section{Conflict of Interest}

The authors confirm that the publication of this article causes no conflict of interest.

\section{References}

1. Emile, F.G. Shehata. (1990). "Fiberreinforced polymer (frp) for shear reinforcement in concrete structures". $\mathrm{Ph} . \mathrm{D}$. Thesis, University of Manitoba, Canada.

2. Bell, T. (n.d) (2018). "How and Why Do Metals Corrode?”. Retrieved May 31, from https://www.thebalance.com/what-is -corrosion-2339700.

3. ACI Committee 222. "Protection of metals in concrete against corrosion (ACI 222R-01)”. ACI Manual of Concrete Practice, American Concrete Institute, Farmington Hills, MI.

4. The international Handbook of FRP COMPOSITES IN CIVIL ENGINEERING. Edited by Manoochehr Zoghi.

5. P. Balagury, A. Nanni, and J. Giancaspro. (2009). "FRP Composites for Reinforced and Prestressed Concrete Structures". 1st ed. Taylor \& Francis. 
6. C. E. Bakis, A. Ganjehlou, D. I. Kachlakev, M. Schupack, P. N. Balaguru, D. J. Gee, V. M. Karbhari, D. W. Scott, C. A. Ballinger, T. R. Gentry, and others, "Guide for the Design and Construction of Externally Bonded FRP Systems for Strengthening Concrete Structures," 2002.

7. H. V. S. GangaRao, N. Taly, and P. V. Vijay, 2007 .Reinforced Concrete Design with FRP Composite, 1st ed. Taylor \& Francis,.

8. ASCE-ACI Committee 426, 1973; "Shear Strength of Reinforced Concrete Members", ASCE Proceedings, Vol. 99. 3T6, June, pp. 1091-1188.

9. ACI Committee 318, 2019; "Building Code Requirements for Reinforced Concrete and Commentary. American Concrete Institute. Detroit.

10. ASCE-ACI Committee 445 on Shear and Torsion, 1998; "Recent Approaches to Shear Design of Structural Concrete," Journal of Structural Engineering. ASCE, Vol.i24. No. 12. December. pp. 1375-1417.

11. Loov, R., 1998; "Review of A23.3-94 Simplified Method of Shear Design and Comparison with Results Using Shear Friction, " Canadian Journal of Civil Engineering, Vol. 25. No. 3,june, pp.437-150.

12. Nielsen, M., 1984; "Limit Analysis and Concrete Plasticity." Prentice-Hall, Inc., Englewood Cliffs, New jersey, 421 p.

13. Collins, M., 1972; "Torque-Twist Characteristics of Reinforced Concrete Beams," Symposium on Inelsticity and Non-Linearity in Structural Concrete. University of Waterloo Press, pp. 211231.

14. Collins, M., 1978; "Towards a Rational Theory for RC Members in Shear," Journal of the Structural Division, ASCE, Vol. 104, No. ST4, April. pp. 619-666.
15. Vecchio, F., and M. Collins, 1981; "Stress-Strain Characteristics of Reinforced Concrete in Pure Shear." IABSE Colloquium on Advanced Mechanics of Reinforced Concrete, Delft, Netherlands, pp. 21 1-225.

16. Vecchio. F., and M. Collins, 1982; "The Response of Reinforced Concrete to InPlane Shear and Normal Stresses," Publication No. 82-03, Department of Civil Engineering, University of Toronto, Toronto, $332 \mathrm{pp}$.

17. Pang, X., and T. Hsu, 1992; "Constitutive Laws of Reinforced Concrete in Shear," Research Report UHCEE 92- 1, Department of Civil Engineering, University of Houston, 188 p.

18. Pang. X., and T. Hsu, 1996: "Fixed Angle Softened Truss Model for Reinforced Concrete." ACI Structural Journal, Vol.93, No.2, March-April, pp. 197-207.

19. Vecchio, F., and M. Collins, 1986; "The Modified Compression Field Theory for Reinforced Concrete Elements Subjected to Shear," ACI Structural Journal, Vol.83,No.2, March-April, pp. $219-23$ 1.

20. American Concrete Institute (ACI) Committee 440. (2015). -Guide For The design and Construction of Concrete Reinforced with FRP Bars.\| ACI 440.1R-15, Farmington Hills, MI

21. Canadian Standards Association (CSA). (2014). Canadian Highway Bridge Design Code.l CAN/CSA-S6-14, Rexdale, Ontario, Canada.

22. Japan Society of Civil Engineers (JSCE). (1997). - Recommendation for Design and Construction of Concrete Structures using Continuous Fiber Reinforcing Materials.\| Tokyo.

23. Canadian Standards Association (CSA). (2012). - Design and Construction of Building Components with Fiber 
Reinforced Polymers.॥ CAN/CSAS80612, Rexdale, Ontario, Canada.

24. ISIS Canada, Reinforcing Concrete Structures with Fiber Reinforced Polymers. Design Manual N8 3 Version 2, Canada ISIS Canada Corporation, Manitoba, 2007.

25. El-Sayed AK, El-Salakawy EF, Benmokrane B (2005) Shear strength of one-way concrete slabs reinforced with FRP. ASCE J Compos Constr 9(2):147157

26. El-Sayed AK, El-Salakawy EF, Benmokrane B (2006a) Shear capacity of high-strength concrete beams reinforced with FRP bars. ACI Struct J 103(3):383-389

27. El-Sayed AK, El-Salakawy EF, Benmokrane B (2006b) Shear strength of normal strength concrete beams reinforced with deformed GFRP bars. ACI Struct J 103(2):235-24

28. Li, W., Tang, S., Huang, Z., Yang, X., Shi, T., \& Xing, F. (2020)“Shear behavior of concrete beam reinforced in shear with carbon fiber-reinforced polymer mesh fabric (CFRP-MF) configuration". Engineering Structures, 218, 110828.)).

29. Jumaa, G. B., \& Yousif, A. R . 2019 "Size effect on the shear failure of highstrength concrete beams reinforced with basalt FRP bars and stirrups". Construction and Building Materials, 209, 77-94.)).

30. Osman, B. H., Wu, E., Ji, B., \& Abdulhameed, S. S. (2018) "Effect of reinforcement ratios on shear behavior of concrete beams strengthened with CFRP sheets". HBRC journal, 14(1), 29-36.

31. Kim, H., Kim, M. S., Ko, M. J., \& Lee, Y. H (2015)." Shear behavior of concrete beams reinforced with GFRP shear reinforcement". International journal of polymer science,
32. Abdul Hamid, Noor Azlina, Rendy Thamrin, and Azmi Ibrahim. (2013)"Shear capacity of non-metallic (FRP) reinforced concrete beams with stirrups.".

33. Kotynia, Renata, Monika Kaszubska, and Joaquim AO Barros. 2018"Shear Behavior of Steel or GFRP Reinforced Concrete Beams Without Stirrups." High Tech Concrete: Where Technology and Engineering Meet. Springer, Cham,. 769-777.

34. Issa, M. A., Ovitigala, T., \& Ibrahim, M. (2016). Shear behavior of basalt fiber reinforced concrete beams with and without basalt FRP stirrups. Journal of Composites for Construction, 20(4), ,04015083 